Argonne

\title{
Updates to the Corn Ethanol Pathway and Development of an Integrated Corn and Corn Stover Ethanol Pathway in the GREETTM Model
}

Energy Systems Division 


\begin{abstract}
About Argonne National Laboratory
Argonne is a U.S. Department of Energy laboratory managed by UChicago Argonne, LLC under contract DE-AC02-06CH11357. The Laboratory's main facility is outside Chicago, at 9700 South Cass Avenue, Argonne, Illinois 60439. For information about Argonne and its pioneering science and technology programs, see www.anl.gov.
\end{abstract}

\title{
DOCUMENT AVAILABILITY
}

Online Access: U.S. Department of Energy (DOE) reports produced after 1991 and a growing number of pre-1991 documents are available free via DOE's SciTech Connect (http://www.osti.gov/scitech/)

Reports not in digital format may be purchased by the public from the National Technical Information Service (NTIS):

U.S. Department of Commerce

National Technical Information Service

5301 Shawnee Rd

Alexandra, VA 22312

www.ntis.gov

Phone: (800) 553-NTIS (6847) or (703) 605-6000

Fax: (703) 605-6900

Email: orders@ntis.gov

Reports not in digital format are available to DOE and DOE contractors from the Office of Scientific and Technical Information (OSTI):

U.S. Department of Energy

Office of Scientific and Technical Information

P.O. Box 62

Oak Ridge, TN 37831-0062

www.osti.gov

Phone: (865) 576-8401

Fax: (865) 576-5728

Email: reports@osti.gov

\footnotetext{
Disclaimer

This report was prepared as an account of work sponsored by an agency of the United States Government. Neither the United States Government nor any agency thereof, nor UChicago Argonne, LLC, nor any of their employees or officers, makes any warranty, express or implied, or assumes any legal liability or responsibility for the accuracy, completeness, or usefulness of any information, apparatus, product, or process disclosed, or represents that its use would not infringe privately owned rights. Reference herein to any specific commercial product, process, or service by trade name, trademark, manufacturer, or otherwise, does not necessarily constitute or imply its endorsement, recommendation, or favoring by the United States Government or any agency thereof. The views and opinions of document authors expressed herein do not necessarily state or reflect those of the United States Government or any agency thereof, Argonne National Laboratory, or UChicago Argonne, LLC.
} 
Updates to the Corn Ethanol Pathway and Development of an Integrated Corn and Corn Stover Ethanol Pathway in the GREET ${ }^{\mathrm{TM}}$ Model

by

Zhichao Wang, Jennifer B. Dunn, Michael Q. Wang

Energy Systems Division, Argonne National Laboratory

September 2014 



\section{CONTENTS}

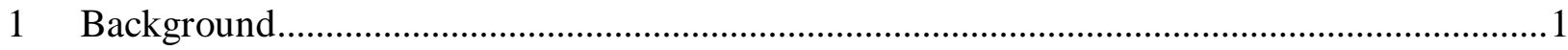

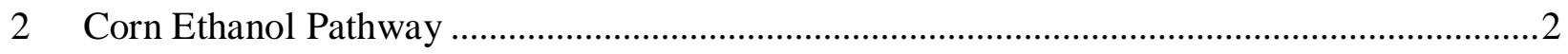

2.1 Chemical Inputs and Energy Use during Corn Production ........................................2

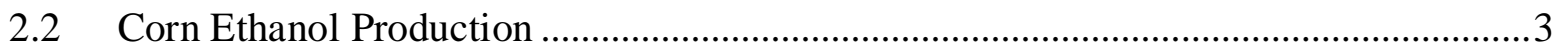

2.3 Corn Oil Co-product Treatment Techniques..............................................................

3 Integrated Corn and Corn Stover Ethanol Pathway .......................................................... 7

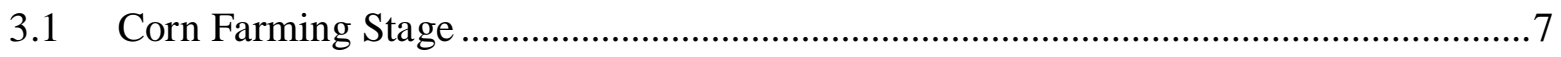

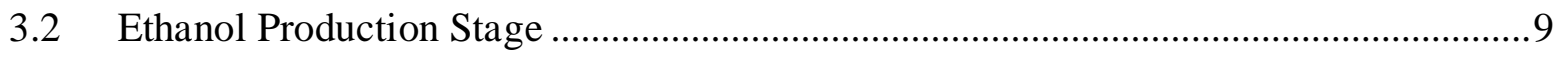

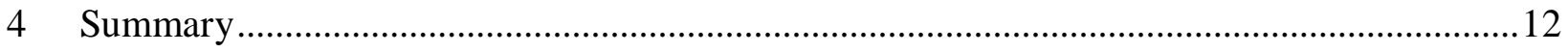

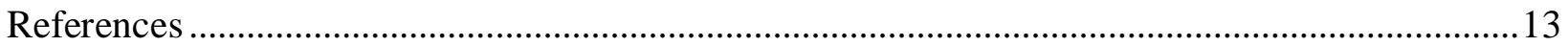

\section{FIGURES}

1 New co-product treatment methods incorporated into the corn ethanol pathway to handle co-produced corn oil use as a biodiesel feedstock ...................................................... 6

2 Integration of corn and corn stover ethanol production at biorefinery ................................. 10

\section{TABLES}

Table 1 Comparison between NASS 2010 survey data and extrapolated NASS 2005 survey

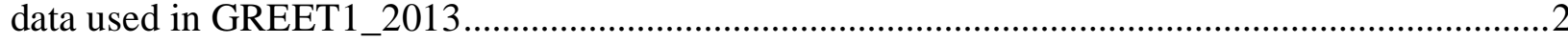

Table 2 Dry grind corn ethanol parameter update summary ..................................................

Table 3 Corn farming energy allocation between corn grain and corn stover ......................... 9

Table 4 Default values for key parameters in the integrated corn and corn stover ethanol pathway 11

Table 5 GHG emissions for corn grain and corn stover ethanol combined or separated under different CHP-produced energy allocation scenarios 


\section{Updates to the Corn Ethanol Pathway and Development of an Integrated Corn and Corn Stover Ethanol Pathway in the GREET TM Model Zhichao Wang, Jennifer B. Dunn, Michael Q. Wang September 2014}

\section{BACKGROUND}

Corn ethanol, a first-generation biofuel, is the predominant biofuel in the United States. In 2013, the total U.S. ethanol fuel production was 13.3 billion gallons, over $95 \%$ of which was produced from corn (RFA, 2014). The 2013 total renewable fuel mandate was 16.6 billion gallons according to the Energy Independence and Security Act (EISA) (U.S. Congress, 2007). Furthermore, until 2020, corn ethanol will make up a large portion of the renewable fuel volume mandated by Renewable Fuels Standard (RFS2).

Despite the dominant position of corn ethanol in today's biofuel market, other biofuels, including cellulosic biofuels and algal fuels, are gaining attention. In the United States, corn stover is considered a promising cellulosic feedstock because it has high availability (DOE, 2011). It is the feedstock for several cellulosic ethanol plants at or near commercialization such as those owned by DuPont, POET-DSM, and Abengoa Bioenergy (Fuels America, 2014). Co-located corn stover and corn ethanol plants have the potential to reduce the costs, energy consumption, and greenhouse gas (GHG) emissions of ethanol production because these facilities could burn the corn stover, or its lignin fraction, to produce process energy, reducing the need for consumption of fossil energy sources such as natural gas. Moreover, process utility integration between the grain- and stover-based ethanol plants is a possibility that could also reduce energy consumption and subsequent GHG emissions (Kaliyan et al., 2014; Sokhansanj et al., 2010). In fact, some companies, including POET-DSM, are planning to bring such co-located ethanol facilities online (http://poet.com/cellulosic).

Given the ongoing importance of corn ethanol and its status as a biofuel bellwether and benchmark, this pathway in Argonne National Laboratory's (Argonne's) Greenhouse gases, Regulated Emissions and Energy use in Transportation (GREET ${ }^{\mathrm{TM}}$ ) model is subject to periodic updates. As reported in Wang et al. (2011) and Chum et al. (2014), advancements in corn agriculture and energy efficiency improvements at corn ethanol plants have reduced the energy and GHG intensity of corn ethanol.

For the GREET1_2014 release, the corn ethanol pathway was subject to updates reflecting changes in corn agriculture and at corn ethanol plants. In the latter case, we especially focused on the incorporation of corn oil as a corn ethanol plant co-product. Section 2 covers these updates. In addition, GREET now includes options to integrate corn grain and corn stover ethanol production on the field and at the biorefinery. These changes are the focus of Section 3. 


\section{CORN ETHANOL PATHWAY}

This section describes the updates to the GREET corn ethanol pathway since the 2013 release, including both the corn agriculture (Section 2.1) and corn ethanol production (Section 2.2) stages of the corn ethanol life cycle.

\subsection{Chemical Inputs and Energy Use during Corn Production}

The U.S. Department of Agriculture's (USDA's) National Agricultural Statistics Service (NASS) Agricultural Chemical Use Program is an important and reliable data source for on-farm chemical use and pest management practices. Since 1990, on a rotating basis for different agricultural commodities, NASS has surveyed U.S. farmers to collect information on the chemicals they apply to these agricultural commodities. The most recent survey for corn production was conducted in 2010 in 19 states (Colorado, Georgia, Illinois, Indiana, Iowa, Kansas, Kentucky, Michigan, Minnesota, Missouri, Nebraska, New York, North Carolina, North Dakota, Ohio, Pennsylvania, South Dakota, Texas, and Wisconsin) (NASS, 2013). The 19 states surveyed produced $95 \%$ (11.8 billion bu) of the total corn grain in the nation (12.4 billion bu) in 2010. Therefore, the average application rate in the 19 states (dividing the total usage by total production) can be regarded as reasonably representative for U.S. domestic corn agriculture. In the previous version of GREET (GREET1_2013), the 2010 chemical application rates were extrapolated from 2005 NASS survey data, the most recent data available at that time. Table 1 shows the comparison between the 2010 NASS survey data and the projected 2010 data used in GREET1_2013. Nitrogen and phosphorus fertilizer application rates calculated from the two data sets are essentially identical, whereas the potassium application rate is about $12 \%$ lower in the newer data set. The herbicide and insecticide application rates changed by $46 \%$ and $-84 \%$, respectively. These application rates are fairly low on an absolute basis and are several orders of magnitude lower than that of nitrogen, phosphorus, and potassium fertilizer application rates. The new data based on the USDA NASS 2010 values are integrated into GREET1_2014.

\section{Table 1 Comparison between NASS 2010 survey data and extrapolated NASS 2005 survey data used in GREET1_2013}

\begin{tabular}{lccc}
\hline & \multicolumn{2}{c}{ 2010 Survey Data } & $\begin{array}{c}\text { 2010 Application Rate } \\
\text { in GREET1_2013 } \\
\text { Chemicals }\end{array}$ \\
\cline { 2 - 3 } \multicolumn{1}{c}{$\begin{array}{c}\text { Total Usage in } \\
2010(\text { million tons) }\end{array}$} & $\begin{array}{c}\text { Application Rate in } \\
2010(\mathrm{~g} / \mathrm{bu})\end{array}$ & 420 \\
$\mathrm{~N}$ & 5.5 & 420 & 150 \\
$\mathrm{P}_{2} \mathrm{O}_{5}$ & 1.9 & 150 & 170 \\
$\mathrm{~K}_{2} \mathrm{O}$ & 2.0 & 150 & 4.8 \\
$\mathrm{Herbicide} \mathrm{(including}$ & 0.09 & 7.0 & \\
fungicide) & & & 0.4 \\
Insecticide & 0.0008 & 0.06 & \\
\hline
\end{tabular}


Corn farming energy use, including consumption of diesel, natural gas, propane, electricity, etc., is indirectly collected by the USDA in its farm cost surveys conducted every five years. Shapouri et al. summarized these historical data from 1991 to 2005 (Shapouri et al., 1995; Shapouri et al., 2002; Shapouri et al., 2004; Shapouri et al., 2010). The 2005 data remain the most recent data available (Shapouri et al. 2010). The corn farming energy intensity is then unchanged from the value of 9,600 Btu/bu in GREET1_2013. A point of comparison to the 2005 USDA data is a recent 3-year (2010-2012) survey study conducted in six Midwestern statesIllinois, Iowa, Indiana, Kentucky, Ohio, and South Dakota - by STAARS (Strategies Targeting American Agricultural Resources and Sustainability) (STAARS, 2014; Jones, 2014). This study surveyed more than 2,300 corn fields that have areas ranging from 3 to 400 acres. The total production for the included farms was $0.1 \%$ of the total national corn production during those 3 years. The average energy consumption for corn farming at the participating farms is 8,800 Btu/bu, similar to the energy intensity used in GREET. We do not adopt the STAARS value in GREET because of the smaller sample size of the STAARS survey as compared to that used to derive the USDA data.

\subsection{Corn Ethanol Production}

The revision of parameters for corn ethanol production at the biorefinery is based on a recent study by Mueller and Kwik (2013). This study explores the adoption of advanced energy generation and saving technologies and processing technologies at the biorefinery that reduce the energy and environmental footprint of corn ethanol production. The study represents the state of the industry in 2012, and is a follow-up effort to a similar study that benchmarked the industry's performance in 2008 (Mueller and Copenhaver, 2009). Dry grind corn ethanol plants produce around $90 \%$ of U.S. corn ethanol (Chum et al., 2014). Mueller and Kwik (2013) include 50\% of these dry grind plants. One important modification to the GREET corn ethanol pathway is the incorporation of corn oil as a co-product from dry grind because more than $80 \%$ of dry grind plants have adopted corn oil recovery (Riley, 2013). A total of $0.53 \mathrm{lb}$ of this co-product is produced for every bushel of corn that the ethanol plant consumes. Corn oil recovery lowers the distillers grains and solubles (DGS) yield. In addition, electricity consumption increases slightly, whereas natural gas consumption declines by $2 \%$. The GREET corn ethanol pathway was also updated to reflect new data for the dry grind ethanol yield. Table 2 summarizes the modifications made to GREET parameters for dry grind corn ethanol.

Table 2 Dry grind corn ethanol parameter update summary

\begin{tabular}{lrrr} 
& GREET & \multicolumn{1}{c}{ GREET } & \\
\multicolumn{1}{c}{ Parameters } & 2013 & 2014 & \multicolumn{1}{c}{ Units } \\
\hline Corn ethanol yield & 2.80 & 2.82 & gal/bu \\
Energy consumption at plant (Total) & 26,856 & 26,000 & $\mathrm{Btu} / \mathrm{gal}$ \\
$\quad$ Natural gas & 24,323 & 24,000 & $\mathrm{Btu} / \mathrm{gal}$ \\
$\quad$ Electricity use & 0.74 & 0.75 & $\mathrm{kWh} / \mathrm{gal}$ \\
Co-product yield & & & \\
$\quad$ DGS & 15.76 & 15 & dry lb/bu \\
Corn oil & - & 0.53 & dry lb/bu \\
\hline
\end{tabular}


It is possible that the recovery of corn oil from the DGS could influence its performance as an animal feed and the corresponding treatment in GREET of dried DGS (DDGS) as displacing conventional animal feed. The displacement ratios of DDGS for corn and soybean meals in various livestock diets could vary from 1:1 (GREET, 2013; Mumm et al., 2014; Widmer et al., 2008; Xu et al., 2010) to as high as 1.2:1 in beef cattle diets (Hoffman and Baker, 2011). Currently in GREET, the displacement ratios of $1 \mathrm{lb}$ DDGS for corn, soybean meal $(\mathrm{SBM})$, and urea are $0.751 \mathrm{lb}, 0.320 \mathrm{lb}$, and $0.024 \mathrm{lb}$, respectively, giving a total displacement ratio of 1.095:1 (Arora et al., 2008). We examined the literature to assess whether these ratios should change when corn oil is recovered from DDGS. One report, a livestock growing study (Jolly et al., 2013), compared the effects of condensed distillers solubles (CDS) with and without corn oil removal. CDS is the condensed form of thin stillage, the part of DGS from which corn oil is recovered. For steer production, when CDS is added at $20 \%$ and $40 \%$ inclusion rates in a grass hay diet and at a $40 \%$ inclusion rate in wheat straw or grass diets, fat content had no effect on ending body weight (BW), dry matter intake (DMI), or average daily gain (ADG) but did affect the feed-to-gain ratio (F:G). Steers fed normal fat CDS had a $13.6 \%$ greater $F: G$ than those fed de-oiled CDS at a $20 \%$ inclusion rate. However, when the inclusion rate doubled, steers fed normal fat CDS exhibited only a $1 \%$ greater F:G than those fed de-oiled CDS. Jolly et al.'s (2013) results do not indicate that animal growth rates are affected by corn oil recovery from DGS, although more study is necessary to better understand the influence of this process change on steer production. Mumm et al. (2014) pointed out that the lower fat content of corn-oil-recovered DDGS makes it a potentially ideal feed for dairy cattle. Two studies report that if dairy cattle diets are correctly formulated, there is no indication that milk composition will change when DGS composition changes after corn oil recovery (Mpapho et al., 2006; Kalsheur, 2005). An important indicator of the influence of corn oil recovery on DGS performance as an animal feed could be changes in DGS price since corn oil recovery has increased. A review of recent DGS price trends does not reveal evidence of a price difference between the normal-fat and low-fat DGS (Shurson, 2013), and in fact, no distinction is made between the two types of DGS based on marketing grades or standards. In other words, the price of DGS does not show a clear response to increases in corn oil recovered at dry grind ethanol plants. Given the current lack of sufficient information in the literature at this time, we did not adjust DGS conventional feed displacement ratios in GREET.

\subsection{Corn Oil Co-product Treatment Techniques}

As discussed in Section 2.2, corn oil recovery has been widely adopted in corn ethanol plants. One primary use of recovered corn oil is as a feedstock for biodiesel production. In 2013, 1,068 million pounds of corn oil, $10 \%$ of the total mass of biodiesel feedstock, were used for biodiesel production in the U.S. (EIA, 2014). The volume of biodiesel produced from corn oil is expected to increase in the future, and the U.S. Environmental Protection Agency (EPA) has projected that 680 million gallons of biodiesel could be produced from corn oil recovered from corn ethanol plants in 2022 (EPA, 2010).

GREET1_2013 did not account for corn oil recovery at dry grind corn ethanol plants. The model has, however, included corn oil produced from wet milling corn ethanol plants and assumes it displaces soy oil as cooking oil at a 1:1 ratio. In GREET1_2014, when corn oil 
displaces soy oil, the displacement ratio remains at 1:1 for the corn oil from both the dry and wet milling corn ethanol plant in the absence of reliable data to alter this ratio. Dry grind-produced corn oil is inedible, however, and cannot displace soy-based cooking oil. It can, however, displace soy oil for other uses, including as an animal feed or as biodiesel feedstock.

In GREET up to this point, co-product treatment methodologies for DDGS and ethanol from dry grind ethanol plants included displacement, energy-based allocation, and market-valuebased allocation. These options, labeled as 1,2, and 3 in GREET, have been revised to account for corn oil as an additional co-product. When the displacement method is adopted, corn oil is assumed to displace soy oil for biodiesel production at a ratio of 1:1. Moreover, GREET1_2014 includes three new co-product treatment methodologies to accommodate use of corn oil as a feedstock for biodiesel production. Figure 1 describes these three new co-products methods, which we label as 4, 5, and 6 in this report and in GREET. 


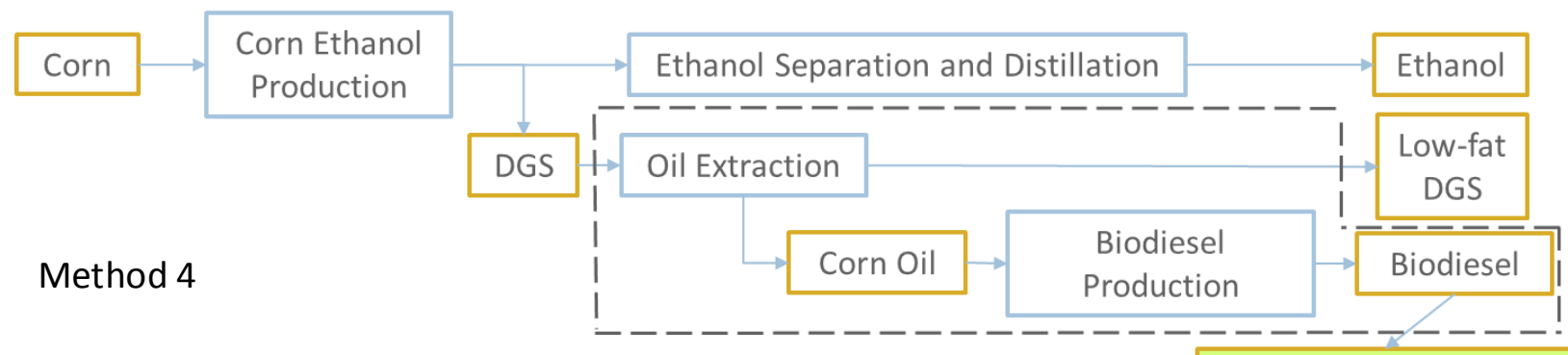

Displace soy biodiesel
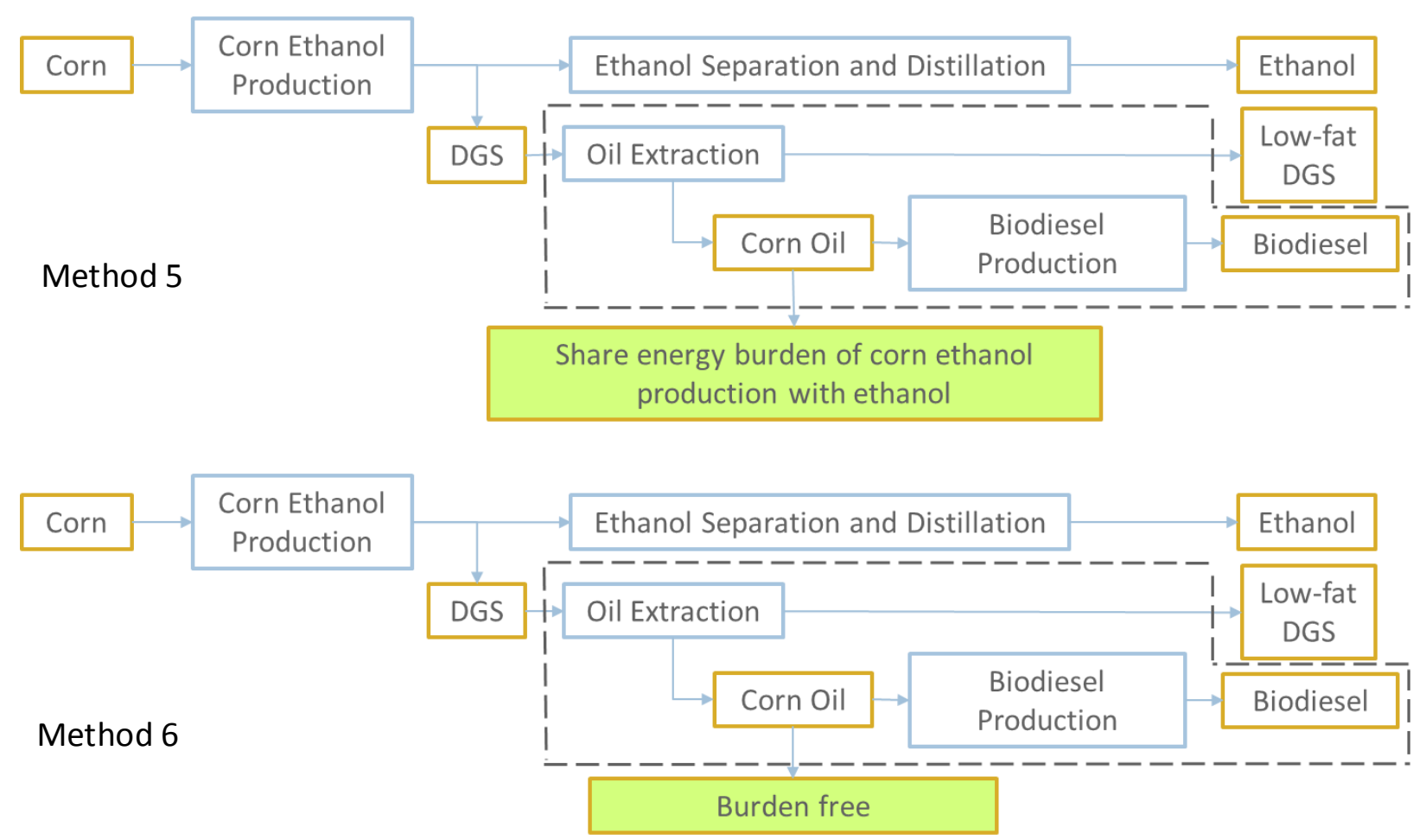
Figure 1 New co-product treatment methods incorporated into the corn ethanol pathway to handle
co-produced corn oil use as a biodiesel feedstock

In methods 4 and 6, the DGS co-product displaces animal feed at the ratios discussed in Section 2.2. In method 4, corn oil biodiesel is assumed to displace soy oil biodiesel and corn ethanol receives the displacement credit. Method 5 takes a process purpose approach. In this method, we examined the energy intensity of the unit operations in the biorefinery, including pretreatment, saccharification, fermentation, ethanol separation, ethanol purification, thin stillage evaporation, and DGS drying (Kwiatkowski et al., 2006), and assigned the energy consumed to either corn ethanol, corn oil, or DGS on the basis of the main purpose of the unit operation. The energy demand for these unit operations is based on a process model of a dry-grind ethanol plant that the USDA developed in Superpro (Kwiatkowski et al., 2006). The energy demand was scaled down to reflect the latest energy consumption data from Mueller and Kwik (2013) because technology improvements have greatly lowered energy consumption during ethanol 
production since the USDA model was created. This method assigns the full energy used for ethanol purification $(4,000 \mathrm{Btu} / \mathrm{gal} \mathrm{EtOH})$ to ethanol, the energy consumption of corn oil recovery $(50 \mathrm{Btu} / \mathrm{gal} \mathrm{EtOH})$ to corn oil, and energy consumption of DGS drying $(8,000 \mathrm{Btu} / \mathrm{gal}$ $\mathrm{EtOH})$ to DGS, and it divides other upstream burdens $(14,400 \mathrm{Btu} / \mathrm{gal} \mathrm{EtOH})$ of ethanol production among ethanol, corn oil and DGS based on energy allocation. In the sixth method, corn ethanol bears the full burden of energy consumption $(26,400 \mathrm{Btu} / \mathrm{gal} \mathrm{EtOH})$ and emissions during ethanol production. In this approach, corn oil is burden-free. It is possible to produce biodiesel from this unburdened feedstock in GREET. Calculating the life-cycle GHG emissions of corn oil biodiesel with methods 5 or 6 yields a value that can be used to assess this biofuel's potential eligibility under the LCFS (Low Carbon Fuel Standard) program of California or the RFS2 (Renewable Fuel Standard) of the EPA.

This expanded treatment of co-products in corn ethanol pathways provides information and options for policy makers and the biofuels community to examine the influence of co-product handling techniques on life-cycle GHG emissions of corn ethanol and corn oil biodiesel.

\section{INTEGRATED CORN AND CORN STOVER ETHANOL PATHWAY}

GREET1_2013 contains separate pathways for corn and corn stover ethanol. GREET1_2014 has been expanded to include an integrated pathway for corn grain and corn stover ethanol production because this integration is a viable possibility for ethanol plants. This integration affects both the feedstock production stage (Section 3.1) and the feedstock conversion stage (Section 3.2).

\subsection{Corn Farming Stage}

Typically, corn stover is harvested after corn grain harvest in a dual-pass system. This approach has been used historically in GREET (Wang et al., 2013). A new pathway has been added to account for integrated corn grain and corn stover ethanol production to model ethanol plants that use both feedstocks.

In the standard GREET treatment of corn stover, only the energy consumed during the harvesting pass to collect the stover and to apply supplemental fertilizer to replace the nutrients in the harvested stover are attributed to corn stover. All other corn agriculture inputs are assigned to the corn grain. Currently, corn stover is still generally regarded as an agricultural residue, not a co-product of corn farming because harvest practices and seed development are focused on grain yield increases, not maximizing stover yield. As corn stover's role as a biofuel feedstock expands, it could be regarded as a co-product, instead of as a residue or waste stream of corn production. In this case, appropriate allocation methods need to be adopted to allocate corn farming energy consumption between corn grain and corn stover. GREET now allows users to take this approach and allocate corn-farming burdens between corn grain and corn stover by energy allocation, mass allocation, and market-value allocation. We use the prices of corn and corn stover estimated in the Billion Ton Study Update (DOE, 2011) for market-value allocation 
at this point. The price used for corn grain is static despite an evolving corn stover market. Energy allocation and market-value allocation are also included in Murphy and Kendall (2013). These authors assumed a higher removal rate of corn stover (1.6 dry tons/acre compared to 0.96 dry tons/acre used in this study), and therefore assigned a higher share of the energy consumed in harvest to corn stover. They allocate $30 \%$ and $15 \%$ of harvest energy to corn stover when energy allocation and market-value allocation methods are used, respectively. In comparison, we use shares of $19 \%$ and $9 \%$ for energy allocation and market-value allocation methods, respectively (Table 3 ).

We have also added an option to harvest corn grain and stover in a single-pass harvest on the basis of a recent report (Herron, 2013). In single-pass harvest, a special harvester collects both the corn grain and corn stover simultaneously (Shinners et al., 2007). This approach could save energy and compact the soil less than existing dual-harvest techniques. To generate the total energy consumed in corn farming with harvest of stover and grain in a single pass, the energy consumption of other non-harvest operations is assumed to be the same as in the dual-pass harvest scenario. Herron (2013) reports the energy consumption for harvesting corn grain in a dual-pass harvesting as $1.3 \mathrm{gal}$ diesel/acre. To generate a value for total energy consumed in a single pass, grain-stover harvest scenario, we subtracted this diesel consumption from that which Shapouri et al. (2010) report and added the diesel consumption Herron (2013) reported for single-pass, grain-stover harvest, $1.8 \mathrm{gal}$ diesel/acre. One drawback of this approach is that Shapouri et al. (2010) do not report the amount of diesel consumed specifically to harvest the corn grain; it is unclear whether it is similar to the fuel consumption Herron reported. To assess whether the 1.3 gal diesel/acre could be sufficiently representative of diesel consumed in corn grain harvest, we examined the STAARs data. In that data set, the share of diesel fuel consumption for corn grain harvest is approximately $19 \%$ of total corn farming energy consumption. Herron's value for corn grain harvest is approximately $11 \%$ of the total corn farming energy Shapouri et al. (2010) report. These shares are sufficiently similar to permit the approach we took to estimating total corn farming energy in a single-pass, grain-stover harvest scenario. A break out of energy consumption by type for each corn farming step would enable an improved energy consumption estimate. Harvest energy consumption for a dual-pass system is documented in an earlier report (Wang et al. 2013). Table 3 contains the results for both harvest methods using different allocation methods. Chemical inputs for corn and corn stover are allocated with the same methods used for allocating energy.

Finally, to reduce soil compaction, farmers may use a "rotating collection" approach to collect the corn stover. For example, instead of collecting $25 \%$ of corn stover from one acre for two consecutive years, farmers could collect $50 \%$ of corn stover from half of this acre in the first year and $50 \%$ of the stover from the other half acre in the second year. With constant yield, the stover mass collected in both of these scenarios would be the same. The second technique could reduce soil compaction but could also reduce soil carbon stocks. GREET currently does not include a rotation collection option in the absence of sufficient data to inform fuel consumption and other parameters. As ethanol plants that use corn stover come on line, real-world stover harvesting techniques will become better understood and GREET will be modified to reflect available corn and stover harvesting data. 
Table 3 Corn farming energy allocation between corn grain and corn stover

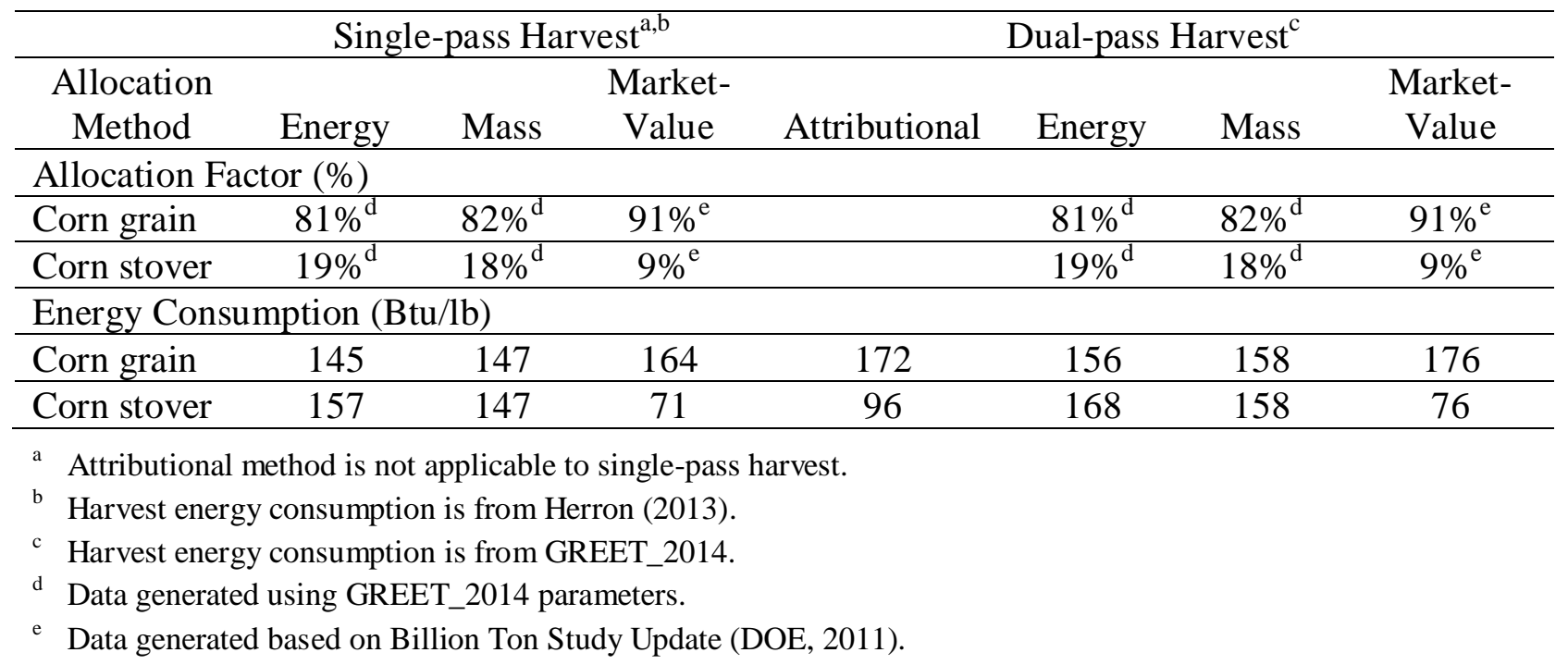

\subsection{Ethanol Production Stage}

In the new integrated pathway, both corn grain and corn stover are ethanol plant inputs. Corn stover can be a process fuel or ethanol feedstock. In the latter case, the lignin fraction that cannot be converted to ethanol is combusted to fulfill a fraction of the process heat and electricity demand (Humbird et al., 2011).

Wallace et al. (2005) investigated six different scenarios for integrating corn grain and corn stover ethanol production. In the first scenario, only process utilities are shared between the two conversion trains. In the second, ethanol purification for the two trains is combined. The third scenario combines the distillation and purification steps for the two trains. The remaining three scenarios differ in their treatment of the fermentation step. Scenario 4 combines starch and cellulose fermentation. Scenario 5 assumes advances in fermentation technology and combines starch and six carbon sugar fermentation. Combined starch and stover fermentation is adopted in the sixth scenario. These last three scenarios are beyond the current state of the technology, which precludes co-fermentation of corn grain and components of corn stover. The second and third scenarios could be feasible but have not yet been demonstrated. We therefore adopt only the first scenario in GREET at this time, as illustrated in Figure 2. The heat and electricity generated from the CHP unit that combust the lignin fraction of corn stover or corn stover feedstock, or both, is subtracted from the total heat and electricity demand of the two ethanol production processes. The heating value of the lignin fraction is adopted from Humbird et al. (2011). The other parameters related to CHP including efficiencies are from GREET. Users can input the fraction of corn stover feedstock that is burned as process fuel, and can adjust the ratio of steam and electricity generated in the CHP unit. 


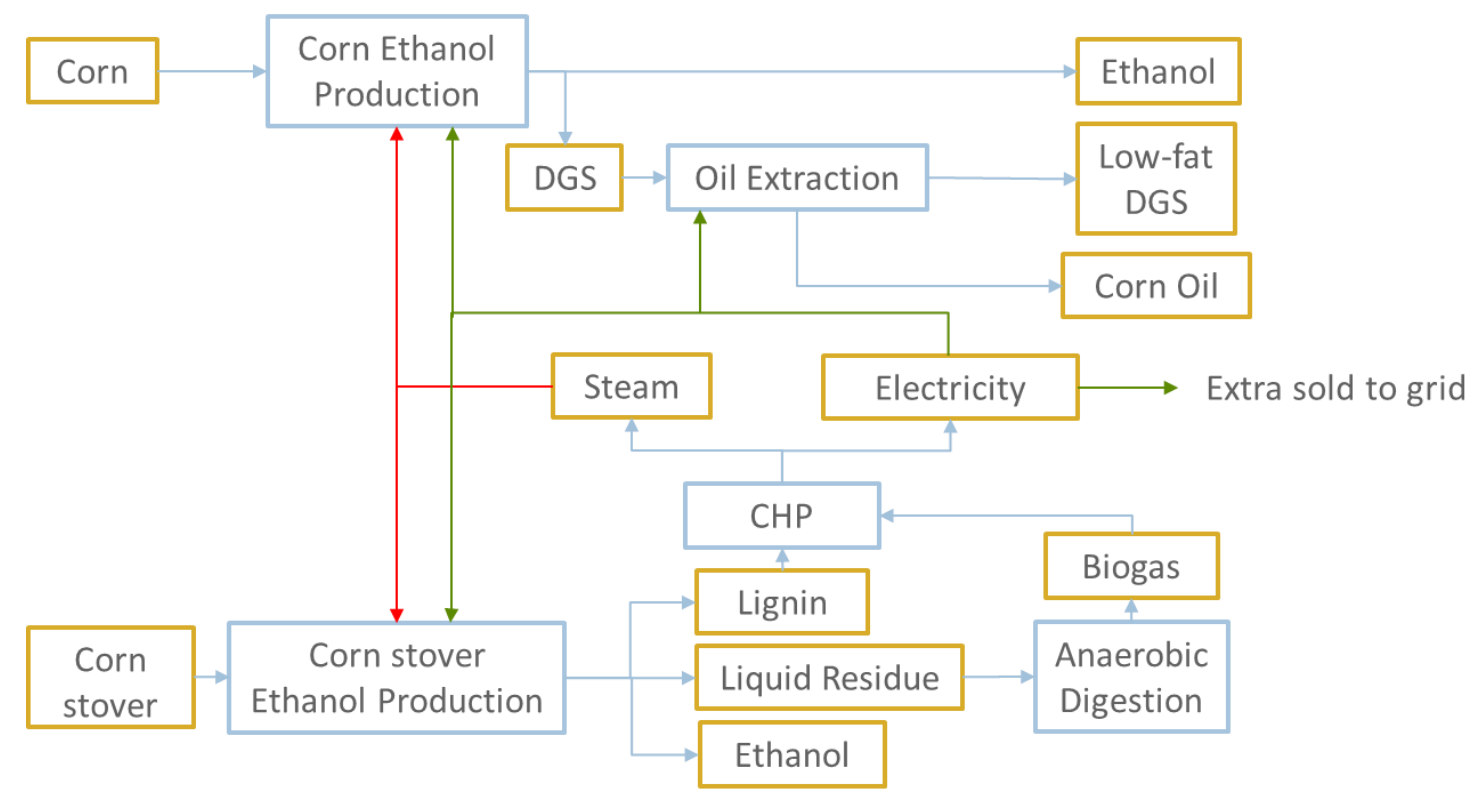

Figure 2 Integration of corn and corn stover ethanol production at biorefinery

In GREET, energy and materials consumption within the whole biorefinery is calculated, and the final results are expressed using the functional unit of $1 \mathrm{mmBtu}$ (or $1 \mathrm{MJ}$ ) ethanol produced. This ethanol is a mixture of two streams: corn ethanol and corn stover ethanol. In a dry grind ethanol plant converting both corn and corn stover to ethanol, possible co-products include DGS, corn oil, and electricity (from corn stover and/or lignin combustion). GREET assumes DGS displaces animal feed and corn oil displaces non-edible soy oil, while either displacement or energy allocation methods can be selected for treating excess electricity. This method of treating DGS and corn oil is the same as that found in Method 1, as mentioned in Section 2.3. The amount of electricity generated depends on user inputs for the CHP process and the split of corn stover between process fuel and process feedstock. It needs to be mentioned that the lignin and biogas that is used for the CHP unit is not assigned any upstream burden from corn agriculture and ethanol production and essentially burden-free.

GREET also provides an option that calculates the energy consumption and GHG emissions for the individual streams of ethanol produced from corn and corn stover, respectively. An accounting issue arises in the handling of the heat and electricity generated from combusting corn stover and/or lignin because they are consumed in both the corn ethanol and corn stover ethanol production processes. This accounting issue is especially important in cases when the heat and electricity generated by the CHP unit are insufficient to meet total energy demand. To address this issue, GREET provides three options for allocating the co-produced heat and electricity. Option 1 uses the heat and electricity to meet the energy demands of corn ethanol production first, with surplus energy sent to the corn stover ethanol process. Option 2 prioritizes the corn stover ethanol process and applies surplus heat and electricity toward the energy demands of the corn ethanol process. This option will be practiced at the POET-DSM plant, which proposes to use energy generated from lignin combustion to fulfill the demand of its corn stover ethanol process first. Excess energy will be used in the corn grain ethanol process 
(http://www.poetdsm.com/liberty). Option 3 allocates the heat and electricity based on the shares of ethanol produced from corn and corn stover.

The default values for some of the key parameters in GREET for this pathway are listed in Table 4. The default mass ratio of corn grain and corn stover input to the biorefinery is based on the assumption that a corn ethanol plant producing 55 million gal per year and a corn stover ethanol plant producing 20 million gal per year are co-located. Such plant sizes are proposed by POET-DSM (http://www.poetdsm.com/liberty; http://poet.com/emmetsburg). This assumption gives a mass ratio of $26 \mathrm{lb}$ dry corn stover/bu corn. It is assumed that 0.96 dry tons of corn stover (Wang et al., 2013) and 158 bu shels of corn grain (GREET) are harvested from a 1-acre corn field. However, it is possible that a higher mass ratio of stover-to-corn grain be used in an actual biorefinery because in the default scenario, the energy generated from the CHP unit can only fulfill a small fraction of the ethanol production energy demand. Increasing the mass ratio of corn stover-to-corn grain at the biorefinery generates more GHG emissions-related reduction benefits because lower amounts of fossil fuels are consumed.

\section{Table 4 Default values for key parameters in the integrated corn and corn stover ethanol pathway}

\begin{tabular}{|c|c|c|}
\hline Parameter & Value & Unit \\
\hline Mass ratio of corn grain and corn stover at biorefinery & 26 & lb stover/bu corn \\
\hline Percentage of corn stover used for ethanol production & 100 & $\%$ \\
\hline Energy from lignin fraction ${ }^{a}$ & 4,100 & btu/lb corn stover converted \\
\hline $\begin{array}{l}\text { Percentage of steam from lignin combustion sent to } \\
\text { CHP unit steam turbine }\end{array}$ & 100 & $\%$ \\
\hline $\begin{array}{l}\text { Allocation method for the generated heat and } \\
\text { electricity }\end{array}$ & 1 & $\begin{array}{l}\text { Fulfill corn ethanol energy } \\
\text { demand first }\end{array}$ \\
\hline
\end{tabular}

a Humbird et al. (2011).

Table 5 shows the GHG emissions results for corn grain and corn stover ethanol combined or separated when the default values in Table 4 are used. Table 5 clearly shows that the methods for allocating the heat and electricity from lignin and/or stover combustion between corn grain ethanol and corn stover ethanol greatly influence the GHG emissions of these two ethanol types, although the emissions for the combined ethanol are constant. These results include land-use change (LUC) GHG emissions. The GREET LUC GHG emissions for corn ethanol were applied only to that biofuel. Corn stover ethanol associated LUC GHG emissions were applied only to corn stover ethanol. 
Table 5 GHG emissions for corn grain and corn stover ethanol combined or separated under different CHP-produced energy allocation scenarios

\begin{tabular}{lccc}
\hline & \multicolumn{2}{c}{ GHG Emissions $\left(\mathrm{g} \mathrm{CO}_{2} \mathrm{e} / \mathrm{MJ}\right)$} \\
\cline { 2 - 4 } $\begin{array}{c}\text { Allocation Method for the Heat and Electricity } \\
\text { Generated by CHP }\end{array}$ & $\begin{array}{c}\text { Combined Corn } \\
\text { and Corn } \\
\text { Stover Ethanol }\end{array}$ & $\begin{array}{c}\text { Corn } \\
\text { Ethanol }\end{array}$ & $\begin{array}{c}\text { Corn Stover } \\
\text { Ethanol }\end{array}$ \\
\hline $\begin{array}{l}\text { Fulfill corn ethanol energy demand first } \\
\text { Fulfill corn stover ethanol energy demand first }\end{array}$ & 48 & 32 & 88 \\
$\begin{array}{l}\text { Allocated based on shares of corn and corn } \\
\text { stover ethanol products }\end{array}$ & 48 & 54 & 30 \\
\hline
\end{tabular}

\section{SUMMARY}

The GREET corn ethanol pathway is important given the importance of corn ethanol in the United States. Efforts to update this pathway for GREET1_2014 included a general update of corn agriculture and ethanol plant data. In addition, GREET1_2014 allows users to explore different co-product treatments for corn oil, a corn ethanol plant co-product newly added to GREET1_2014. Finally, GREET permits calculation of results for corn grain and corn stover ethanol produced in an integrated facility. As corn agriculture and corn ethanol plant technologies continue to evolve, the corn ethanol pathway in GREET will be revised accordingly. 


\section{REFERENCES}

Arora, S., Wu, M., and Wang, M., 2008. Update of Distillers Grains Displacement Ratios for Corn Ethanol Life-Cycle Analysis. Argonne National Laboratory. ANL/ESD/11-1.

Chum, H.L., Zhang, Y., Hill, J., Tiffany, D.G., Morey, R.V., Goss Eng, A., and Haq, Z., 2014. Understanding the Evolution of Environmental and Energy Performance of the U.S. Corn Ethanol Industry: Evaluation of Selected Metrics. Biofuels, Bioproducts and Biorefining, 8(2), 224-240.

DOE (U.S. Department of Energy), 2011. U.S. Billion-Ton Update: Biomass Supply for a Bioenergy and Bioproducts Industry. R.D. Perlack and B.J. Stokes (Leads), ORNL/TM2011/224. Oak Ridge National Laboratory, Oak Ridge, TN. 227p.

EIA (Energy Information Administration), 2014. Monthly Biodiesel Production Report with Data for March 2014. Available at http://www.eia.gov/biofuels/biodiesel/production/ biodiesel.pdf, accessed 08/21/2014.

EPA (U.S. Environmental Protection Agency), 2010. Renewable Fuel Standard Program (RFS2) Regulatory Impact Analysis. EPA-420-R-10-006. Available at http://www.epa.gov/otaq/ renewablefuels/420r10006.pdf, accessed 08/21/2014.

Fuels America, 2014. Four Commercial Scale Cellulosic Ethanol Biorefineries to Enter Production This Year. Available at http://www.fuelsamerica.org/blog/entry/four-commercialscale-cellulosic-ethanol-biorefineries-to-enter-production, accessed 08/21/2014.

GREET (Greenhouse gases, Regulated Emissions and Energy use in Transportation), 2013. Argonne National Laboratory. Available at http://greet.es.anl.gov/, accessed 08/21/2014.

Herron, M., 2013. Integration of Advanced Logistical Systems and Focused Bioenergy Harvesting Technologies to Supply Crop Residues and Energy Crops in a Densified Large Square Bale Format. 2013 DOE BETO Project Peer Review.

Hoffman, L.A., Baker A., 2011. Estimating the Substitution of Distillers Grains for Corn and Soybean Meal in the US Feed Complex. USDA ERS. Available at http://www.ers.usda.gov/ media/236568/fds11i01_2_.pdf, accessed 08/21/2014.

Humbird, D., Davis, R., Tao, L., Kinchin, C., Hsu, D., Aden, A., Schoen, P., Lukas, J., Olthof, B., Worley, M., Sexton, D., and Dudgeon, D., 2011. Process Design and Economics for Biochemical Conversion of Lignocellulosic Biomass to Ethanol. Dilute-Acid Pretreatment and Enzymatic Hydrolysis of Corn Stover. Technical Report NREL/TP-5100-47764. 
Jolly, M.L., Schneider, C.J., Nuttelman, B.L., Burken, D.B., Klopfenstein, T.J., and Erickson, G.E., 2013. Effects of Feeding Condensed Distillers Solubles With and Without Oil Extraction on Growing Cattle Performance. 2013 Nebraska Beef Cattle Report. Available at http://beef.unl.edu/c/document_library/get_file?uuid=fb74d3ab-ab1d-4e97-b39dedeb8ef8d21f\&groupId=4178167\&.pdf, accessed 08/21/2014.

Jones, C., 2014. Personal communication, Iowa Soybean Association, on 01/30/2014.

Kaliyan, N., Morey, R.V., Tiffany, D.G., and Lee, W.F., 2014. Life Cycle Assessment of a Corn Stover Torrefaction Plant Integrated with a Corn Ethanol Plant and a Coal Fired Power Plant. Biomass and Bioenergy, 63, 92-100.

Kalscheur, K.F., 2005. Impact of Feeding Distillers Grains on Milk Fat, Protein, and Yield. In Proceedings of the Distillers Grains Technology Council's 9th Annual Symposium, May 18-19, 2005; Louisville, KY. Ames, IA: DGTC; 2005.

Kwiatkowski, J.R., McAloon, A.J., Taylor, F., and Johnston, D.B., 2006. Modeling the Process and Costs of Fuel Ethanol Production by the Corn Dry-grind Process. Industrial Crops and Products, 23(3), 288-296.

Mpapho, G.S., Hippen, A.R., Kalscheur, K.F., and Schingoethe, D.J., 2006. Lactational Performance of Dairy Cows Fed Wet Corn Distillers Grain for the Entire Lactation [abstract]. J Dairy Sci. 90:100.

Mueller, S., and Copenhaver, K., 2009. An Analysis of Modern Corn Ethanol Plant Technologies. Report prepared for Illinois Corn Marketing Board. Available at http://www.erc.uic.edu/assets/ pdf/EthanolPlantTechnologyReport2_1609.pdf, accessed 08/21/2014.

Muller, S., and Kwik, J., 2013. 2012 Corn Ethanol: Emerging Plant Energy and Environmental Technologies. Available at http://ethanolrfa.3cdn.net/fe5f4b7a4bdbc12101_2gm6bejk4.pdf, accessed 08/21/2014.

Mumm, R.H., Goldsmith, P.D., Rausch, K.D., and Stein, H.H., 2014. Land Usage Attributed to Corn Ethanol Production in the United States: Sensitivity to Technological Advances in Corn Grain Yield, Ethanol Conversion, and Co-product Utilization. Biotechnology for Biofuels, 7(1), $1-17$.

Murphy, C.W., and Kendall, A., 2013. Life Cycle Inventory Development for Corn and Stover Production Systems under Different Allocation Methods. Biomass and Bioenergy, 58, 67-75.

NASS (National Agricultural Statistics Service), 2013. Quickstat Database. Available at http://quickstats.nass.usda.gov/, accessed 08/21/2014.

RFA (Renewable Fuels Association), 2014. Historic U.S. Fuel Ethanol Production. Available at http://www.ethanolrfa.org/pages/statistics, accessed 08/21/2014. 
Riley, J., 2013. Maintaining and Increasing Corn Oil Value. Available at http://www.fecsolutions.com/pdf/presentations/MaintainingAndIncreasingCornOilValue.pdf, accessed 08/21/2014.

Shapouri H, Duffield JA, Graboski MS. Estimating the New Energy Balance of Corn Ethanol. Washington, D.C.: U.S. Department of Agriculture, Economic Research Service; July, 1995. 15 p. Report No.: AER-721.

Shapouri H, Duffield JA, Wang M. The Energy Balance of Corn Ethanol: an Update. Washington, D.C.: U.S. Department of Agriculture, Office of the Chief Economist, Office of Energy Policy and New Uses; July, 2002. 16 p. Report No.: AER-814.

Shapouri H, McAloon A. The 2001 Energy Balance of Corn Ethanol. Washington, D.C.: U.S. Department of Agriculture, Office of Chief Economist; 2004. 6 p.

Shapouri H, Gallagher PW, Nefstead W, Schwartz R, Noe S, Conway R. 2008 Energy balance for the Corn-ethanol Industry. Washington D.C.: U.S. Department of Agriculture, Office of the Chief Economist, Office of Energy Policy and New Uses; June, 2010. 15 p. Report No.:

AER-846.

Shinners, K.J., Adsit, G.S., Binversie, B.N., Digman, M.F., Muck, R.E., and Weimer, P.J., 2007. Single-pass, Split-stream Harvest of Corn Grain and Stover. Trans. ASABE, 50(2), 355-363.

Shurson, J., 2013. Distillers Corn Oil and Impact on DDGS Feeding Value and Price. Available at http://www.pannoniagold.com/wp-content/uploads/Distillers-Corn-Oil-and-Impact-on-DDGSFeeding-Value-final-10-29-13.pdf, accessed 08/21/2014.

Sokhansanj, S., Mani, S., Tagore, S., and Turhollow, A.F., 2010. Techno-economic Analysis of Using Corn Stover to Supply Heat and Power to a Corn Ethanol Plant-Part 1: Cost of Feedstock Supply Logistics. Biomass and Bioenergy, 34(1), 75-81.

STAARS (Strategies Targeting American Agricultural Resources and Sustainability), 2014. Available at http://www.iasoybeans.com/environment/programs-initiatives/programs/staars, accessed 08/21/2014.

U.S. Congress, 2007. Public law 110-140, Energy Independence and Security Act of 2007, Washington, D.C.

Wallace, R., Ibsen, K., McAloon, A., and Yee, W., 2005. Feasibility Study for Co-Locating and Integrating Ethanol Production Plants from Corn Starch and Lignocellulosic Feedstocks. NREL/TP-510-37092, USDA-ARS 1935-41000-055-00D.

Wang, M.Q., Han, J., Haq, Z., Tyner, W.E., Wu, M., and Elgowainy, A., 2011. Energy and Greenhouse Gas Emission Effects of Corn and Cellulosic Ethanol with Technology Improvements and Land Use Changes. Biomass and Bioenergy, 35(5), 1885-1896. 
Wang, Z., Dunn, J.B., Han, J., and Wang, M., 2013. Material and Energy Flows in the Production of Cellulosic Feedstocks for Biofuels for the GREET ${ }^{\mathrm{TM}}$ Model. ANL/ESD-13/9. Argonne National Laboratory, Argonne, Ill.

Widmer, M.R., McGinnis, L.M., Wulf, D.M., and Stein, H.H., 2008. Effects of Feeding Distillers Dried Grains with Solubles, High-protein Distillers Dried Grains, and Corn Germ to Growingfinishing Pigs on Pig Performance, Carcass Quality, and the Palatability of Pork. J Anim Sci. 86:1819-1831.

Xu, G., Baidoo, S.K., Johnston, L.J., Bibus, D., Cannon, J.E., and Shurson, G.C., 2010. Effects of Feeding Diets Containing Increasing Content of Corn Distillers Dried Grains with Solubles to Grower-finisher Pigs on Growth Performance, Carcass Composition, and Pork Fat Quality. J Anim Sci. 88:1398-1410. 



\section{Argonne}

\section{Energy Systems Division}

9700 South Cass Avenue, Bldg. 362

Argonne, IL 60439-4815

www.anl.gov 